\title{
The Influence of Founder Status on Firm Performance: Empirical Evidence from Canadian IPO Firms
}

\author{
Saif Ullah ${ }^{1} \&$ Dan Zhang ${ }^{1}$ \\ ${ }^{1}$ John Molson School of Business, Concordia University, Montreal, Canada \\ Correspondence: Saif Ullah, John Molson School of Business, Concordia University, 1450 Rue Guy, Montreal, \\ QC, H3H 0A1, Canada. E-mail: saif.ullah@Concordia.ca
}

Received: September 7, 2016

Accepted: October 4, 2016

Online Published: October 25, 2016

doi:10.5539/ijef.v8n11p134

URL: http://dx.doi.org/10.5539/ijef.v8n11p134

\begin{abstract}
This study compares performance for founder-managed firms and professional-managed firms by analyzing 138 Canadian IPO firms that went public from 2004 to 2013. In this paper, we measure firm performance in two ways: Tobin's Q and ROA are used to measure a firm's financial performance, while firm survival status is used as a supplementary performance measure. We find that founder-managed firms underperform and underlive their counterparts when firm performance is measured by Tobin's Q and survival status. Founder status is proved to be unrelated to ROA. The negative influence of founder status can be explained by the relevant transaction hypothesis, which states that founder-managers may act for the controlling family and are more concerned with the associated private income stream than with maximizing the value of the firm.
\end{abstract}

Keywords: Canadian IPOs, founder-CEO, founder-director, firm performance, family business

\section{Introduction}

The role of a founder in creating and running a company is an interesting phenomenon that has attracted research interest. Several research studies have examined whether founder-managed firms tend to perform differently than non-founder-managed firms. The majority of the research studies show that the presence of a founder-CEO or founder-director is associated with better firm performance (Cohen et al., 2013; Fahlenbrach, 2009; Willard et al., 1992), and this can be explained by the greater financial and nonfinancial ties that provide founders with both the abilities and incentives to offer better monitoring when they are involved in firm management (Li \& Srinivasan, 2011). However, the performance of professionally managed firms, in some cases, is not systematically or statistically significantly inferior to that of founder-managed firms. For instance, Brown et al. (2005) find that firms with a founder CEO have lower long-run stock returns. Jayaraman et al. (2000) study 94 founder- and non-founder-managed firms and find that founder management has no main effect on stock returns over a 3-year holding period.

Canada and the United States share a common legal ancestry and developed public equity markets. In the United States, public firms are generally widely held; however, a large number of publicly traded firms in Canada are controlled by family shareholders (Erickson et al., 2005; King \& Santor, 2008; Morck et al., 2000). This divergence makes the application of the founder-status effect in the Canadian market a mystery. To date, no empirical work has attempted to determine whether founder status makes a difference to the firm's value for Canadian companies, let alone for Canadian initial public offering (IPO) firms. By utilizing updated data, we aim at filling the gap in Canadian IPO firms.

In this paper, we measure firm performance in two ways: market-based measure Tobin's $Q$ and accounting measure return on assets ratio (ROA) are used to indicate firm financial performance, while firms' survival status is used as a supplementary performance measure. Accordingly, this study is partitioned into two major sections. The first stage discusses the relationship between founder status and firm financial performance, and the second stage focuses on the effects of founder status on the firm's survival probability.

By using a data sample that consists of 138 Canadian IPO firms for the period 2004 through 2013, we find that founder status has no influence on firm performance measured by ROA, while founder firms underperform professionally managed firms in regard to Tobin's Q, which is robust when founders serve as chair members. Besides, founder status is significantly negatively related with survival probability, suggesting that 
founder-managed firms not only underperform but also underlive their counterparts.

We test the relevant transaction hypothesis as an explanation for this phenomenon. This hypothesis states that founder-managers may act in the interests of the controlling family and are more concerned with the associated private income stream than with maximizing the value of the firm.

\section{Literature Review}

In recent years, several research studies have examined whether founder-managed firms tend to perform differently than non-founder-managed firms. The findings of these studies have been inconsistent.

The majority of research papers show that the presence of a founder-CEO or founder-director is associated with better firm performance. Willard et al. (1992) believe that many founders can and do successfully manage growth. Adams et al. $(2005,2009)$ find that "CEO = founder" is positively and significantly correlated both with Tobin's Q and with ROA, measurements of corporate performance. Using a novel data set, Fahlenbrach (2009) demonstrates that founder-CEO firms not only have a higher valuation but also better stock market performance. By comparing non-founder-led firms to founder-led firms, Cohen et al. (2013) find marginally significant evidence that high-ability founder-led firms have larger impacts on future returns than do non-founder-led firms. Besides, Anderson et al. (2003), Anderson and Reeb (2003a, 2003b), Andres (2008), Maury (2006), and Villalonga and Amit $(2006,2009)$ all find that family firms, particularly when founders serve as CEO or chairman of the board, tend to be associated with better performance and higher valuation in developed economies.

The greater financial and nonfinancial ties provide founders with both the abilities and the incentives to offer better monitoring when they are involved in firm management (Li \& Srinivasan, 2011). On one hand, their long involvement in the creation and management of the enterprise enables them to accumulate specific knowledge about the firm and the industry. Randall et al. (1988) suggest that founder CEOs bring innovative and value-enhancing expertise to the firm. Founders also bring contacts, prestige, and expertise from prior experiences, and the founders' network is a key antecedent to building subsequent relationships, for example, those useful for venture capital financing (Burton et al., 2002; Eisenhardt \& Schoonhoven, 1990; Hallen, 2008; Shane \& Stuart, 2002). On the other hand, founder-CEOs often have a strong passion for the ventures they found (Chen et al., 2009), and such passion is likely to be further strengthened by the significant challenges they face in leading the ventures (Aldrich \& Fiol, 1994; Stinchcombe \& March, 1965). Founder-director companies are also associated with fewer agency problems and are better governed than are nonfounder companies (Li \& Srinivasan, 2011). The combination of these factors, as well as the founder's nonpecuniary attachment (e.g., reputational and emotional), leads to increased firm value (Demsetz \& Lehn, 1985; James, 1999; Li \& Srinivasan, 2011).

However, it is also possible and not unusual to replace the initial human assets (founders) and find other people to run the firm (Kaplan et al., 2009). The performance of professionally managed firms, in some cases, is not systematically or statistically significantly inferior to that of founder-managed firms. Lauterbach and Vaninsky (1999) and Schulze et al. (2001) all demonstrate that founder/family firms underperform vis-à-vis the market. Brown et al. (2005) find that firms with a founder CEO have lower long-run stock returns. Jayaraman et al. (2000) study 94 founder- and non-founder-managed firms and find that founder management has no major effect on stock returns over a 3-year holding period. Palia (2001) argues that the founder dummy is not statistically significantly related to firm value, represented by Tobin's Q. One explanation is that founders and founding families may be more concerned with maintaining control of a business and its associated private income stream than with maximizing the value of the firm (Chandler, 2009). To the extent that a founder's interests diverge from those of the firm's other shareholders and manifest in the form of excessive consumption, poor performance may result (Jensen \& Meckling, 1976).

Three points are worth noting regarding the relationship of founder-management status and firm performance. First, a founder may have an opposite effect when serving as a CEO and a director. Brown et al. (2005) find evidence that the continued involvement of the founders as members of the board has a positive impact on the long-term performance of the roll-up firm. However, the coefficient on the founder CEO dummy is negative, helping explain why firms with a founder-CEO have lower long-run stock returns. A similar conclusion by $\mathrm{Li}$ and Srinivasan (2011) shows a higher value with the presence of a founder-director, but an insignificant coefficient on the founder-CEO variable. Villalonga and Amit (2006) believe that compared with the value of founders as CEO, "founders' skills are almost as valuable when they bring them to the firm through a position as Chairman with a hired CEO in place" (404).

As the majority of founder-managed firms are family-controlled firms, we must separate the influence of founders and their heirs on firm performances. Founder descendants have passion and commitment to their firms. 
However, their lack of prestige and expertise, which must be obtained from prior working experience, may destroy a firm. Morck et al. (2000) find that firm value tends to be lower when the firm is run by a member of the founder's family than when it is run by an unrelated officer. Anderson and Reeb (2003a) conclude that market performance appears to be better only in the presence of founder CEOs and outside CEOs; founder descendants serving as CEO have no effect on market performance. Using Fortune 500 firms, Villalonga and Amit (2006) report that family ownership creates value only when the founder serves as CEO of the family firm or as chairman with a hired CEO. In contrast, firm value is destroyed when descendants serve as CEOs. Pérez-González (2006) finds that firms with family succession underperform relative to firms that promote unrelated CEOs. In the context of Canada, Attig (2007) finds that small shareholders face a higher level of agency problems and a risk of expropriation in family-controlled firms. Chourou (2010) finds that, in Canada, family CEOs receive higher compensation than their nonfamily counterparts in family-controlled firms. Both of these studies look at family firms with differential controlling rights.

Last, but not least, finding a positive relation between founder involvement and performance is not necessarily an indication that founder involvement causes future performance. Founders' impact on firm performance might be the result of poor-performing firms replacing founder CEOs with professional CEOs. In other words, reverse causality on founder-performance link is a possibility. Adams et al. (2005, 2009), Brown et al. (2005), and He (2008) take the causality test into consideration. Adams et al. $(2005,2009)$ use instrumental variables methods to isolate the effects of founder-CEO status on firm performance from other sources of performance and conclude that the positive correlation is consistent with causation running from "CEO = founder" to firm performance. He (2008) takes advantage of a generalized linear model with binomial distribution to estimate the relation between CEO succession and firm performance.

An IPO represents an important milestone in the evolution of an entrepreneurial firm as it progresses from a start-up to a public corporation. The choice of founder versus non-founder-managers at the time of going public represents a significant decision made by the IPO firm. However, only a few research studies look at the effect of founder status on firm performance in IPO firms. Nelson (2003) provides evidence that the presence of a founder-CEO at the time of an IPO results in higher firm valuations. He (2008) compares founder-CEOs with professional CEOs in newly public firms and concludes that founder-managed firms are associated with higher financial performance (measured by ROA) and are more likely to survive than are professionally managed firms. To better understand founders' role in these transitional firms, this study compares founder-managers in newly public firms with their professional counterparts in terms of firm performance.

This study is also meaningful in that we take advantage of Canadian data. The majority of existing studies draw conclusions based on the U.S. data, while to date, no empirical work has attempted to determine whether founder status makes a difference to the firm's value for Canadian companies, let alone for Canadian IPO firms. A large number of publicly traded firms in Canada are proven to be controlled by family shareholders, unlike in the United States, where most public companies are widely held by individual investors (Daniels \& Halpern, 1996). This divergence motivated us to investigate whether the founder-status effect applies in the Canadian market. By utilizing an updated data, we aim at filling the gap in Canadian IPO firms.

\section{Hypotheses}

Referring to the literature above, two contradicting viewpoints exist: founder-managed firms statistically outperform professionally managed firms, and founder-managers underperform professionally managed firms. Noticing that the majority of previous research studies show a positive effect of founder status on firm performance, we cannot ignore that these studies are based on the United States. Of the limited studies focused on other countries, Tsao et al. (2009) study 688 Taiwanese firms listed on the Taiwan Stock Exchange and conclude that the "founder-CEO was found not to be associated with firm performance." Sacristan-Navarro et al. (2011) study 118 nonfinancial Spanish companies and conclude that "once endogeneity issues were considered, it was found that founder involvement did not influence profitability." Regarding the Canadian market, empirical work has not explored founder-status effect, and only a few studies related the controlling family to a firm's performance. Morck et al. (2000) find a negative correlation between heir control in Canadian firms and firm performance. Markin (2004) analyzes a sample of 251 Canadian firms and demonstrates that Canadian family firms are not more profitable than are non-family-owned firms.

Canada and the United States share a common legal ancestry, with the Canadian corporate and securities laws adopted from American precedents. Similar to the United States, Canada is a country in which public equity markets are well developed. At the same time, however, a large number of publicly traded firms in Canada are controlled by family shareholders (Erickson et al., 2005; King \& Santor, 2008; Morck et al., 2000). Morck and 
Yeung (2003) propose an agency problem in family firms: in family business group firms, managers may act for the controlling family, but not for shareholders, in general. They argue that some family-controlled firms organized into business groups to obtain outside equity financing. The entrenchment of controlling families and non-arm's-length transactions between related companies is detrimental to public investors. Chandler (2009) also holds that founders and founding families may be more concerned with maintaining control of a business and its associated private income stream than with maximizing the value of the firm. Obviously, these kinds of agency problems occur more in founder-managed firms because the founder firm is a special kind of family-controlled firm. On the contrary, professionally hired managers in nonfounder firms are less likely to be implicated in relevant transactions, thus attracting more investors. In light of this, professionally managed firms may perform better than founder-involved firms.

Based on the above arguments, we obtain the following three hypotheses:

Hypothesis I: In the Canadian market, founder-managed firms UNDERPERFORM professionally managed firms, ceteris paribus.

Hypothesis II: In the Canadian market, founder-managed firms UNDERLIVE professionally managed firms, ceteris paribus.

Hypothesis III: The negative relationship is caused by the relevant transaction hypothesis. More precisely, founder-managers may act for the controlling family and are more concerned with the associated private income stream than with maximizing the value of the firm.

\section{Methodology}

\subsection{Measurements of Firm Performance}

Past research has used both market-based and accounting measures as indicators of firm financial performance. Examples are Tobin's Q and return on assets (ROA). Tobin's Q is mostly utilized as a market-based measure, and ROA is an accounting measure. Demsetz andVillalonga (2001) and Narayanan et al. (2000) choose Tobin's Q to represent firm performance. Gary and Birger (1989) and John et al. (1999) employ ROA as a proxy for firm performance. Hamid (1995) and Ronald and David (2003) combine the two measurements.

The measures differ from one another in two important ways. ROA is backward looking, and Tobin's Q is forward looking; ROA focuses on firms' short-term performance, and Tobin's Q is more concerned with long-term firm value. The second difference concerns which actually measures performance. As an accounting measure, ROA is constrained by standards set by the accounting profession. Demsetz and Villalonga (2001) state that Tobin's $\mathrm{Q}$ is primarily constrained by the acumen, optimism, or pessimism of investors.

In this paper, we measure firms' financial performance in two ways: Tobin's $Q$ and ROA. Firms' survival status is used as a supplementary performance measure. The test using Tobin's Q captures whether founder-status impacts market value, while the relation between founder-status and ROA captures the effect of power on accounting performance.

In this study, Tobin's Q is measured by Malmendier and Tate (2008) by the equations expressed as follows:

$$
\text { Tobin's } \mathrm{Q}=\text { Market value of assets/Book value of assets }
$$

where the market value of assets equals the total assets, plus the market equity, minus book equity. Market equity equals common shares outstanding, multiplied by the fiscal-year closing price. Book equity equals total assets, minus total liability, minus preferred stock, plus deferred tax plus convertible debt. Book value of assets equals total assets.

ROA is calculated as operating income before depreciation and amortization (OIBDP), scaled by the average book value of total assets. We believe that OIBDP is a better way to calculate ROA than is net income in that OIBDP is a measure of income exclusive of the effects of a company's capital spending choices. It also does not reflect the cash used for debt service, distributions, or other non-core-operating expenses. OIBDP gives investors a better sense of how efficiently a company operates purely based on its ability to create and sell its product or service.

For entrepreneurial firms facing the "liability of newness," survival is the bottom-line in market competition. Using survival status to measure performance also helps to correct for the truncation problem in the use of financial performance data $(\mathrm{He}, 2007)$. We define firms dropping from the public market for various reasons as having a death event and create a dummy variable survival status. Survival status equals " 1 " if firms still exist in the public stock market and " 0 " if firms have a death event. 


\subsection{Definition of Founder Status}

As we stated in literature review, a founder may have an opposite effect when serving as a CEO and director. Therefore, we separate the impact of founders by creating two dummy variables: founder-CEO and founder-director. Founder-CEO equals " 1 " if the founder or co-founder is CEO and " 0 " otherwise, where the CEO is the top executive of the firm. If a firm has no CEO, the chairman (or president in the absence of a chairman) is assumed to be the top executive of the firm. Founder-director equals " 1 " if the founder or co-founder is on the board (not necessarily a chairman) and "0" otherwise. We use Villalonga and Amit's (2009) method to define founders:

1). Executives who are described as founders in the prospectus, proxy statement, or annual statement.

2). Executives who are identified as founders in at least two public sources and no other data source that we are aware of mentions a different person as the founder.

\subsection{Control Variables}

Since our purpose is to examine the effect of founder status on firm performance, we control for other determinants of firm performance. A total of fourteen control variables, of which we divide into two groups, are applied here. They are either proven to be significantly related to firm performance, in previous research, or are regarded as related, theoretically.

First, we introduce several control variables into our analysis to control for industry and firm characteristics. Total asset turnover is a financial ratio that measures the efficiency of a company's use of its assets in generating sales revenue or sales income to the company. The long-term-debt-to-asset ratio measures the extent of a company's leverage. Firm size is the natural log of the book value of total assets, as size alone is not normally distributed. Firm age is measured as the natural log of the number of years since the firm's inception (see Adams et al., 2009; Li \& Srinivasan, 2011). Industry dummy variables are constructed based on two-digit SIC codes and adjusted for the observation numbers of different industries. The details of adjustment will be interpreted in the data. The crisis dummy is created in consideration of the financial crisis from 2007-2008. Firms that went public during the financial crisis are assigned a " 1 " and "0" otherwise. Venture capital involvement is measured by a dummy variable that takes on the value of " 1 " if the IPO-issuing firm received venture capital backing and " 0 " otherwise (see Jain \& Tabak, 2008). We take advantage of the Bloomberg Commodity Index (BCOM) change, a highly liquid and diversified benchmark for commodities investments, as a proxy of macroeconomic conditions. Detailed definitions for and the sources of these variables are provided in the Appendix.

Because corporate governance mechanisms can also influence firm performance, we include proxies for various governance devices. CEO tenure is a measure of CEOs' firm-specific human capital (see He, 2008). CEO ownership measures the percentage of firm ownership held by the CEO (see Adams et al., 2009; Hamid, 1995; Li \& Srinivasan, 2011; Nelson, 2003). Board size (see Li \& Srinivasan, 2011) is measured of the natural log of the number of directors on the board. Principal shareholder ownership is the percentage of equity held by principal shareholders, where we define principal shareholders as shareholders who own at least $10 \%$ of a company's common shares. Insider ownership is measured by dividing the number of common stock of all nominees, directors, and executive officers by the total number of outstanding common stocks. The percentage of independent board members (see Li \& Srinivasan, 2011) is also utilized to control for corporate governance.

\subsection{Regression Framework}

This study is partitioned into two major sections. The first stage discusses the relationship between founder status and firm financial performance, and the second stage focuses on the effects of founders' status on firms' survival probability, thus comprehensively revealing how founders' status influences firm performance.

\subsubsection{Multiple Linear Regression Analysis}

We take advantage of multiple linear regressions to explore the effect of founder status on firm financial performance. Because we employ both Tobin's Q and ROA to represent financial performance and separate the effect of founder-CEO and founder-director, a total of four functions are included.

The model is listed as below:

$$
Y_{i}=\beta_{0}+\beta_{1} F O U N D E R_{0 i}+\beta_{2} v i+\beta_{3} w_{i}+\varepsilon_{i}
$$

where $Y_{i}$ represents Tobin's $\mathrm{Q}$ and ROA, respectively. FOUNDER $R_{0 i}$ refers to the dummy variables founder-CEO and founder-director, respectively. $v i$ and $w_{i}$ represent financial and governance controls, respectively.

Three points are noteworthy regarding the regression. First, firm financial performance is measured one year 
after the IPO to investigate a manager's ability during this year. The subscript 0 in the variable FOUNDER $R_{0 i}$ reflects this consideration. Second, we build three sub-models within each of the four regressions, with the first model adding firm and industry variables only, the second including corporate governance variables only, and the third taking both groups into consideration. The last point is inspired by McConnell and Servaes (1990), who found strong evidence of a curvilinear relation between insider ownership and Tobin's Q. This makes sense because the influence may be nonlinear in the whole range. Therefore, we may add CEO ownership squared and insider ownership squared, in case of a curvilinear relationship.

\subsubsection{Logistical Regression Analysis}

In this part, we investigate the impact of founder involvement on firm's survival status, that is, whether a firm survives. A cross-sectional logistic regression is used here because the dependent variable, survival status, is a binary variable. The logistic model, which is estimated by the maximum likelihood method, can be set as follows:

$$
\log \left(\frac{\pi_{i}}{1-\pi_{i}}\right)=\beta_{0}+\beta_{1} \text { FOUNDER } R_{0 i}+\beta_{2} v_{i}+\beta_{3} w_{i}+\varepsilon_{i}
$$

where $\pi_{i}$ represents the probability that a firm still exists and FOUNDER $R_{0 i}$ represents founder-CEO and founder-director, respectively. $v_{i}$ and $w_{i}$ represent the financial and governance controls, respectively.

\section{Data Description}

The data used in the analysis are a sample of firms going public in Canadian market from 2004 to 2013. We collect sample firms that issued initial public offerings from the Securities Data Corporation (SDC) New Issues Database. Consistent with the vast majority of IPO studies, we exclude financial companies, real estate investment trusts, reverse LBOs, equity carve-outs, foreign issuers, and unit offerings as their institutional characteristics are fundamentally different from that of a typical IPO firm. We also delete firms that change their CEOs during the first year after IPO. Further, we require that IPO prospectuses are available for each firm and that financial data are available from the COMPUSTAT database.

The financial information used in calculating firm performances and firm characteristics controls is obtained from the COMPUSTAT database. Information on founder status, CEO tenure, ownership, board characteristics, and other corporate governance controls is not available in public compensation databases and is manually collected from these firms' prospectuses and annual proxy statements reported to the Canadian Securities Administrators (CSA) using the CSA's SEDAR filling system. The data concerning venture capital involvement are available in the SDC database, and the BCOM data are collected from Bloomberg. Specific descriptions and the data source are shown in Table A.1 (see the Appendix).

Finally, we obtain a data sample that consists of 138 IPO firms in total for the period 2004-2013. In investigating the data, we find some extreme values for Tobin's Q and ROA. Those outliers are processed on $90 \%$ winsorization, meaning all data below the 5th percentile are set to the 5th percentile, and data above the 95th percentile are set to the 95 th percentile.

Table 1 summarizes the observation numbers classified by year and industry. Table 1 shows booming initial public offering market in 2007 and a shrinking IPO market in 2013. Generally speaking, IPO numbers decrease in the latter five years when compared to the former five years.

Table 1. IPO numbers by year and industry

\begin{tabular}{|c|c|c|c|}
\hline Year & No. of IPOs & Industry & No. of IPOs \\
\hline 2004 & 11 & Agriculture, forestry, and fishing & 0 \\
\hline 2005 & 22 & Mining & 80 \\
\hline 2006 & 13 & Construction & 0 \\
\hline 2007 & 29 & Manufacturing & 27 \\
\hline 2008 & 12 & Transportation, communications, electric, gas, and sanitary service & 11 \\
\hline 2009 & 3 & Wholesale trade & 1 \\
\hline 2010 & 19 & Retail trade & 3 \\
\hline 2011 & 15 & Finance, insurance, and real estate & 2 \\
\hline 2012 & 10 & Services & 14 \\
\hline \multirow[t]{2}{*}{2013} & 4 & Public administration & 0 \\
\hline & 138 & Total & 138 \\
\hline
\end{tabular}

Note. This table reports IPO firms by year and industry. 
For industry classification, mining occupies more than half of the IPO firms, and manufacturing also takes over a big percentage. According to this particular case, we make an adjustment about industry classification that combines the remaining industry into "other industries" ( 31 observations in total) and set "other industries" as the base in industry dummies.

Table 2 reveals the summary statistics of all the variables, grouped by firm performance, founder status, firm and industry characteristics and governance structure. Five basic statistics are listed.

Table 2. Summary statistics

\begin{tabular}{llccccc}
\hline & & Mean & Median & SD & Min & Max \\
\hline Firm performance & Tobin's Q & 2.00 & 1.38 & 1.81 & 0.43 & 7.92 \\
& ROA & -0.14 & -0.06 & 0.36 & -1.25 & 0.25 \\
& Survival status & 0.71 & 1.00 & 0.46 & 0.00 & 1.00 \\
& Founder-CEO & 0.54 & 1.00 & 0.50 & 0.00 & 1.00 \\
Firm and industry & Founder-director & 0.67 & 1.00 & 0.47 & 0.00 & 1.00 \\
characteristics & Total asset turnover & 0.36 & 0.14 & 0.50 & 0.00 & 2.42 \\
& Long-term-debt-to-asset ratio & 0.13 & 0.01 & 0.24 & 0.00 & 1.94 \\
& Firm size & 4.17 & 4.47 & 2.07 & -2.40 & 9.38 \\
& Firm age & 8.95 & 3.71 & 16.76 & 1.17 & 119.00 \\
& Mining & 0.58 & 1.00 & 0.50 & 0.00 & 1.00 \\
& Manufacturing & 0.20 & 0.00 & 0.40 & 0.00 & 1.00 \\
& Financial crisis & 0.39 & 0.00 & 0.49 & 0.00 & 1.00 \\
& Venture capital involvement & 0.10 & 0.00 & 0.30 & 0.00 & 1.00 \\
Governance structure & BCOM change (\%) & -9.13 & -2.71 & 18.74 & -50.82 & 27.08 \\
& CEO tenure & 3.83 & 2.50 & 3.26 & 0.33 & 19.00 \\
& CEO ownership (\%) & 8.31 & 4.15 & 10.96 & 0.00 & 57.47 \\
& Board size & 1.80 & 1.79 & 0.28 & 1.10 & 2.57 \\
& Principal shareholder ownership (\%) & 27.85 & 24.58 & 24.15 & 0.00 & 92.82 \\
& Insider ownership (\%) & 17.14 & 12.28 & 16.15 & 0.04 & 74.51 \\
& Independent board member (\%) & 66.24 & 66.67 & 15.89 & 0.75 & 88.89 \\
\hline
\end{tabular}

Note. This table reports summary statistics for sample firms. Variable definitions are provided in Appendix A.

Table 2 shows that the mean value of Tobin's Q varies from its median, and for ROA, mean and median are close to each other, with a much smaller standard deviation. The mean value of founder-CEO and founder-director shows a higher percentage of founder-involvement in directors. Table 3 provides comparative descriptive data for the subsamples of founder-CEOs and non-founder CEOs, founder-directors, and non-founder-directors, respectively. The $p$-value from the ANOVA F-test is presented to reject the null hypothesis of equal mean when comparing two groups. Of the 138 IPO firms between 2004 and 2013, 75 firms (54.35\%) are managed by founder-CEOs and 92 firms (66.67\%) are managed by founder-directors.

Table 3. Comparisons between founder firms and nonfounder firms

\begin{tabular}{|c|c|c|c|c|c|c|}
\hline Variables & $\begin{array}{c}\text { Founder } \\
\text { CEO }\end{array}$ & $\begin{array}{c}\text { Nonfounder } \\
\text { CEO }\end{array}$ & $\begin{array}{l}\text { ANOVA } \\
p \text {-value }\end{array}$ & $\begin{array}{l}\text { Founder } \\
\text { director }\end{array}$ & $\begin{array}{c}\text { Nonfounder } \\
\text { director }\end{array}$ & $\begin{array}{l}\text { ANOVA } \\
p \text {-value }\end{array}$ \\
\hline Tobin's Q & 1.78 & 2.26 & 0.12 & 1.69 & 2.62 & 0.00 \\
\hline ROA & -0.10 & -0.19 & 0.15 & -0.11 & -0.20 & 0.13 \\
\hline Survival status & 0.65 & 0.78 & 0.11 & 0.66 & 0.80 & 0.09 \\
\hline Total asset turnover & 0.39 & 0.33 & 0.46 & 0.38 & 0.33 & 0.54 \\
\hline Long-term-debt-to-asset ratio & 0.16 & 0.10 & 0.17 & 0.15 & 0.09 & 0.21 \\
\hline Firm size & 4.35 & 3.95 & 0.26 & 4.42 & 3.67 & 0.04 \\
\hline Firm age & 6.94 & 11.34 & 0.12 & 6.81 & 13.22 & 0.03 \\
\hline BCOM change $(\%)$ & -9.61 & -8.56 & 0.74 & -9.52 & -8.35 & 0.73 \\
\hline CEO tenure & 4.49 & 3.04 & 0.01 & 4.10 & 3.29 & 0.17 \\
\hline CEO ownership (\%) & 12.01 & 3.89 & 0.00 & 10.12 & 4.67 & 0.01 \\
\hline Board size & 6.15 & 1.81 & 0.51 & 1.80 & 1.79 & 0.79 \\
\hline Principal shareholder ownership (\%) & 26.45 & 29.53 & 0.46 & 25.74 & 32.08 & 0.15 \\
\hline Insider ownership (\%) & 20.21 & 13.49 & 0.01 & 18.31 & 14.81 & 0.23 \\
\hline Independent board member $(\%)$ & 67.88 & 64.28 & 0.19 & 66.77 & 65.17 & 0.58 \\
\hline
\end{tabular}

Note. This table compares different variables across founder and nonfounder CEOs and founder directors and nonfounder directors. Variable definitions are provided in Appendix A. 
Table 3 shows that when firm performances are measured by Tobin's $Q$ and survival probability, founder-managed firms underperform professionally managed firms. The difference is robust for comparisons regarding directors. For ROA, no significant differences are observed. In addition, founder-CEOs have longer tenure and hold more stocks than do nonfounder CEOs. The average insider ownership for founder-CEO firms (20.21\%) is significantly higher than that of the non-founder firms, which is almost $7 \%$ less.

The phenomenon that the CEO owns more common shares also exists in founder-director firms, of which CEOs, on average, own $10.12 \%$ of the firm, compared with $4.67 \%$ in non-founder-director firms. Meanwhile, founder-director firms are significantly bigger than their counterparts, although the difference in magnitude is negligible. Founder firms are also about 6.5 years younger.

\section{Empirical Results}

We investigate the impact of founder status on firm financial performance, indicated by the market-based measure Tobin's Q and the accounting measure ROA, and then focus on the effects of founder status on the firm's survival probability.

\subsection{Multiple Linear Regression Analysis}

Tables 4-7 reveal the empirical results of the regressions that study the effect of founder status on firm financial performance. In each table, Columns 1, 2, and 3 show the regression results controlled by firm and industry characteristics only, by corporate governance structure only, and by both of the two groups, respectively.

Table 4 shows that founder-CEO firms are associated with poor performance measured by Tobin's Q. However, this negative relationship is only robust when adding governance structure as control variables. The coefficient estimate of founder-CEO is -0.7191 , suggesting that the average of Tobin's Q value for founder-CEO firms is 0.7191 lower than that of non-founder-CEO firms. The coefficient is economically, as well as statistically, significant.

Table 4. Founder-CEO effect on firm performance measured by Tobin's $Q$

\begin{tabular}{lccc}
\hline & Model 1 & Model 2 & Model 3 \\
\hline Intercept & $4.1946(7.89)^{* * * *}$ & $4.6988(3.80)^{* * *}$ & $4.2637(3.25)^{* * *}$ \\
Founder-CEO & $-0.2786(-1.00)$ & $-0.7191(-2.21)^{* *}$ & $-0.4308(-1.35)$ \\
Total asset turnover & $0.3344(1.01)$ & - & $-0.0306(-0.08)$ \\
Long-term-debt-to-asset ratio & $0.2548(0.40)$ & - & $0.2900(0.45)$ \\
Firm size & $-0.4347(-5.72)^{* * *}$ & - & $-0.3087(-3.21)^{* * *}$ \\
Firm age & $-0.0038(-0.40)$ & - & $-0.0075(-0.77)$ \\
Mining & $-0.0238(-0.06)$ & - & $0.0692(0.16)$ \\
Manufacturing & $0.2165(0.47)$ & - & $0.6950(1.48)$ \\
Financial crisis & $-0.6180(-2.01)^{* *}$ & - & $-0.6418(-2.08)^{* *}$ \\
Venture capital involvement & $0.0865(0.17)$ & - & $0.2305(0.43)$ \\
BCOM change $(\%)$ & $0.0162(1.99)^{* *}$ & $-0.0175(-0.36)$ & $-0.0178(2.21)^{* *}$ \\
CEO tenure & - & $0.1303(2.48)^{* *}$ & $0.1328(2.60)^{* *}$ \\
CEO ownership $(\%)$ & - & $-0.0033(-3.03)^{* * *}$ & $-0.0032(-2.94)^{* * *}$ \\
CEO ownership squared & - & $-1.1578(-1.97)^{*}$ & $-0.0612(-0.09)$ \\
Board size & - & $0.0069(1.00)$ & $0.0089(1.34)$ \\
Principal shareholder ownership $(\%)$ & - & $-0.0531(-1.47)$ & $-0.0613(-1.78)^{*}$ \\
Insider ownership $(\%)$ & - & $0.0014(2.33)^{* *}$ & $0.0012(2.11)^{* *}$ \\
Insider ownership squared & - & $-0.0099(-1.05)$ & $-0.0097(-1.07)$ \\
Independent board member $(\%)$ & - & 3.82 & 3.90 \\
F-value & 5.36 & 0.16 & 0.28 \\
Adj. ${ }^{2}$ & 0.24 & - & - \\
\hline
\end{tabular}

Note. This table reports effects of founder-CEO on firm performance. Tobin's Q is used as a measure of firm performance. Variable definitions are provided in Appendix A. t-statistics are in parentheses following the coefficient estimates. ***, ** and * indicate level of significance at $10 \%, 5 \%$ and $1 \%$ level.

Among the control variables, coefficients of firm size, financial crisis, BCOM change, CEO ownership, and insider ownership are statistically significant, meaning these control variables do help explain firm performance well. The consideration of a curvilinear relationship between ownership and firm performance and the improvement of adding CEO ownership squared and insider ownership squared works in our data. 
Table 5. Founder-director effect on firm performance measured by Tobin's Q

\begin{tabular}{lccc}
\hline & Model 1 & Model 2 & Model 3 \\
\hline Intercept & $4.4434(8.21)^{* * *}$ & $4.8574(3.98)^{* * *}$ & $4.5327(3.47)^{* * *}$ \\
Founder-director & $-0.6211(-2.06)^{* *}$ & $-0.9241(-2.91)^{* * *}$ & $-0.6535(-2.08)^{* *}$ \\
Total asset turnover & $0.3124(0.95)$ & - & $-0.0354(-0.10)$ \\
Long-term-debt-to-asset ratio & $0.2544(0.41)$ & - & $0.2656(0.42)$ \\
Firm size & $-0.4100(-5.38)^{* * *}$ & - & $-0.2928(-3.06)^{* * *}$ \\
Firm age & $-0.0074(-0.78)$ & - & $-0.0102(-1.04)$ \\
Mining & $-0.1141(-0.28)$ & - & $-0.0182(-0.04)$ \\
Manufacturing & $0.1767(0.39)$ & - & $0.6367(1.36)$ \\
Financial crisis & $-0.5827(-1.96)^{*}$ & - & $-0.6301(-2.07)^{* *}$ \\
Venture capital involvement & $0.1043(0.21)$ & - & $0.2762(0.52)$ \\
BCOM change (\%) & $0.0162(2.01)^{* *}$ & $-0.0249(-0.52)$ & $0.0176(2.21)^{* *}$ \\
CEO tenure & - & $0.1178(2.36)^{* *}$ & $-0.0282(-0.55)$ \\
CEO ownership (\%) & - & $-0.0030(-2.83)^{* * *}$ & $0.1274(2.62)^{* * *}$ \\
CEO ownership squared & - & $-1.0329(-1.77)^{*}$ & $-0.0030(-2.90)^{* * *}$ \\
Board size & - & $0.0056(0.82)$ & $-0.0254(-0.04)$ \\
Principal shareholder ownership (\%) & - & $-0.0478(-1.35)$ & $0.0079(1.21)$ \\
Insider ownership (\%) & - & $0.0013(2.18)^{* *}$ & $-0.0599(-1.76)^{*}$ \\
Insider ownership squared & - & $-0.0111(-1.20)$ & $0.0012(2.07)^{* *}$ \\
Independent board member $(\%)$ & $-0.0107(-1.19)$ \\
F-value & 5.82 & 4.30 & 4.12 \\
Adj. $\mathrm{R}^{2}$ & 0.26 & 0.18 & 0.29 \\
\hline
\end{tabular}

Note. This table reports effects of founder-director on firm performance. Tobin's Q is used as a measure of firm performance. Variable definitions are provided in Appendix A. t-statistics are in parentheses following the coefficient estimates. ***, ** and * indicate level of significance at $10 \%, 5 \%$ and $1 \%$ level.

Table 5 differs from Table 4 only in the founder status. When focused on the founder-director effect, we find a significantly negative relationship between founder-director and Tobin's $Q$ that is supported by the negative coefficient and the absolute value of corresponding $t$-statistics. The negative effects of founder-CEO and founder-director are consistent with Dittmar and Servaes (2005), Lauterbach and Vaninsky (1999), and Schulze et al. (2001), who demonstrate that the performance of founder-managed firms is inferior to that of professionally managed firms.

Unlike the founder-CEO effect, this negative relationship is robust, at least, at a 5\% confidence level, no matter which group of control variables are included. Brown et al. (2005) also find a distinct effect. To further explore the explanation of the difference, we investigate our sample and find that all the founder-CEOs are founder-directors. In other words, in our specific case, a founder-director signifies founder involvement, and this is why the founder-director effect should be more significant.

Tables 6 and 7 are the regression results for when firm performance is measured by ROA. The coefficients of founder status are not statistically significant, suggesting that accounting-based firm performance is unrelated to founder-CEO and founder-director, no matter which group of control variables are added. Villalonga and Amit (2009) also demonstrate an inconsistent conclusion between Tobin's Q and ROA. 
Table 6. Founder-CEO effect on firm performance, measured by ROA

\begin{tabular}{|c|c|c|c|}
\hline & Model 1 & Model 2 & Model 3 \\
\hline Intercept & $-0.5900(-7.35) * * *$ & $-0.7130(-2.87)^{* * *}$ & $-0.1160(-0.58)$ \\
\hline Founder-CEO & $0.0439(1.04)$ & $0.0717(1.10)$ & $0.0285(0.58)$ \\
\hline Total asset turnover & $0.1939(3.86)^{* * *}$ & - & $0.2088(3.62)^{* * *}$ \\
\hline Long-term-debt-to-asset ratio & $-0.4297(-4.50)^{* * *}$ & - & $-0.4335(-4.40)^{* * *}$ \\
\hline Firm size & $0.1181(10.29)^{* * *}$ & - & $0.1358(9.20)^{* * *}$ \\
\hline Firm age & $-0.0018(-1.27)$ & - & $-0.0013(-0.87)$ \\
\hline Mining & $-0.0644(-1.05)$ & - & $-0.0584(-0.90)$ \\
\hline Manufacturing & $-0.0726(-1.04)$ & - & $-0.0892(-1.23)$ \\
\hline Financial crisis & $-0.0054(-0.12)$ & - & $-0.0099(-0.21)$ \\
\hline Venture capital involvement & $-0.0252(-0.33)$ & - & $0.0183(0.22)$ \\
\hline BCOM change (\%) & $0.0008(0.64)$ & - & $0.0009(0.71)$ \\
\hline CEO tenure & - & $0.0178(1.82)^{*}$ & $-0.0004(-0.05)$ \\
\hline CEO ownership (\%) & - & $0.0005(0.05)$ & $0.0004(0.05)$ \\
\hline CEO ownership squared & - & $0.0002(0.96)$ & $0.0000(0.29)$ \\
\hline Board size & - & $0.3374(2.86)^{* * *}$ & $-0.2529(-2.54)^{* *}$ \\
\hline Principal shareholder ownership (\%) & - & $-0.0001(-0.10)$ & $-0.0003(-0.28)$ \\
\hline Insider ownership (\%) & - & $-0.0031(-0.43)$ & $-0.0006(-0.11)$ \\
\hline Insider ownership squared & - & $-0.0001(-0.81)$ & $-0.0000(-0.16)$ \\
\hline Independent board member (\%) & - & $-0.0011(-0.58)$ & $-0.0012(-0.88)$ \\
\hline F-value & 18.75 & 3.57 & 11.15 \\
\hline Adj. $R^{2}$ & 0.56 & 0.14 & 0.57 \\
\hline
\end{tabular}

Note. This table reports effects of founder-CEO on firm performance. ROA is used as a measure of firm performance. Variable definitions are provided in Appendix A. t-statistics are in parentheses following the coefficient estimates. ***, ** and * indicate level of significance at $10 \%$, $5 \%$ and $1 \%$ level.

Table 7. Founder-director effect on firm performance, measured by ROA

\begin{tabular}{lccc}
\hline & Model 1 & Model 2 & Model 3 \\
\hline Intercept & $-0.5697(-6.85)^{* * * *}$ & $-0.7228(-2.90)^{* * * *}$ & $-0.1096(-0.54)$ \\
Founder-director & $-0.0007(-0.02)$ & $0.0568(0.88)$ & $-0.0234(-0.48)$ \\
Total asset turnover & $0.1958(3.88)^{* * *}$ & - & $0.2052(3.56)^{* * *}$ \\
Long-term-debt-to-asset ratio & $-0.4223(-4.41)^{* * *}$ & - & $-0.4204(-4.30)^{* * *}$ \\
Firm size & $0.1194(10.19)^{* * *}$ & - & $0.1387(9.35)^{* * *}$ \\
Firm age & $-0.0021(-1.42)$ & - & $-0.0016(-1.03)$ \\
Mining & $-0.0675(-1.09)$ & - & $-0.0592(-0.91)$ \\
Manufacturing & $-0.0731(-1.05)$ & - & $-0.0892(-1.23)$ \\
Financial crisis & $-0.0016(-0.03)$ & - & $-0.0058(-0.12)$ \\
Venture capital involvement & $-0.0281(-0.37)$ & - & $0.0155(0.19)$ \\
BCOM change $(\%)$ & $0.0008(0.64)$ & - & $0.0009(0.72)$ \\
CEO tenure & - & $0.0188(1.94)^{*}$ & $0.0009(0.11)$ \\
CEO ownership (\%) & - & $0.0002(0.80)$ & $0.0024(0.32)$ \\
CEO ownership squared & - & $0.3342(2.81)^{* * *}$ & $-0.2504(-2.51)^{* *}$ \\
Board size & - & $-0.0002(-0.11)$ & $-0.0004(-0.44)$ \\
Principal shareholder ownership $(\%)$ & - & $-0.0038(-0.53)$ & $-0.0010(-0.20)$ \\
Insider ownership $(\%)$ & - & $-0.0001(-0.72)$ & $-0.0000(-0.09)$ \\
Insider ownership squared & - & $-0.0010(-0.52)$ & $-0.0012(-0.86)$ \\
Independent board member $(\%)$ & 18.49 & 3.51 & 11.13 \\
F-value & 0.56 & 0.14 & 0.57 \\
Adj. $\mathbf{R}^{2}$ & - & $-13)$ \\
\hline
\end{tabular}

Note. This table reports effects of founder-director on firm performance. ROA is used as a measure of firm performance. Variable definitions are provided in Appendix A. t-statistics are in parentheses following the coefficient estimates. $* * *, * *$ and $*$ indicate level of significance at $10 \%, 5 \%$ and $1 \%$ level.

Since ROA measures short-term performance, while Tobin's Q is based on a long-term view, we can summarize the results as in the short-term, founder status has no influence to firm value, but in a long-run, founder-firms underperform professionally managed firms, an outcome that is robust when founders serve as directors. Hence, Hypothesis I is partly verified when firm performance is measured by Tobin's Q. 


\subsection{Logistic Regression Analysis}

Table 8 shows the empirical results of the logistic regressions that study the effect of founder status on firm survival probability.

Table 8 . The effect of founder status on firm performance, measured by survival status

\begin{tabular}{lcc}
\hline & Model 1 & Model 2 \\
\hline Intercept & $3.7885(2.72)^{*}$ & $4.2109(3.26)^{*}$ \\
Founder-CEO & $-0.9987(3.60)^{*}$ & - \\
Founder-director & - & $-1.0018(3.25)^{*}$ \\
Total asset turnover & $-1.0214(3.43)^{*}$ & $-1.0536(3.70)^{*}$ \\
Long-term-debt-to-asset ratio & $0.6358(0.37)$ & $0.4881(0.23)$ \\
Firm size & $-0.1044(0.43)$ & $-0.0911(0.34)$ \\
Firm age & $0.0704(3.02)^{*}$ & $0.0725(2.88)^{*}$ \\
Mining & $-0.2898(0.18)$ & $-0.4188(0.38)$ \\
Manufacturing & $-1.1651(2.36)$ & $-1.2039(2.54)$ \\
Financial crisis & $-0.4839(0.98)$ & $-0.4945(1.04)$ \\
Venture capital involvement & $0.3728(0.19)$ & $0.4730(0.31)$ \\
BCOM change (\%) & $-0.0360(7.26)^{* * *}$ & $-0.0370(7.68)^{* * *}$ \\
CEO tenure & $-0.0385(0.17)$ & $-0.0612(0.47)$ \\
CEO ownership (\%) & $0.1037(6.80)^{* * *}$ & $0.0972(6.36)^{* *}$ \\
Board size & $-0.2760(0.06)$ & $-0.2480(0.05)$ \\
Principal shareholder ownership $(\%)$ & $-0.0113(1.24)$ & $-0.0128(1.38)$ \\
Insider ownership (\%) & $-0.0305(2.17)$ & $-0.0308(2.21)$ \\
Independent board member $(\%)$ & $-0.0161(1.05)$ & $-0.0181(1.41)$ \\
Likelihood ratio & 29.96 & 29.68 \\
\hline
\end{tabular}

Columns 1 and 2 list the regression results of the founder-CEO and founder-director effect, respectively. Founder-managed firms are associated with the smaller survival probabilities in Table 8 . The coefficient estimate of founder-CEO is -0.9987 . This means that the average $\log (\mathbf{o d d s})$ of survival for founder-CEO firms is 0.9987 lower than professional-CEO firms. This relationship is significant with a Wald chi-square value of 3.60. Similarly, the founder-director effect is also negative and robust. Therefore, Hypothesis II, which states that founder-managed firms underlive non-founder-managed firms, is supported.

To conclude the results, founder-managed firms underperform and underlive their counterparts in the long-term. But in the short-term, founder status is proven to be unrelated with firm performance. The effects of founder-CEO and founder-director diversify when firm performance is measured by Tobin's Q.

\section{Discussion and Interpretation}

In the empirical results, we conclude a long-run poor performance for founder firms, so take a further step and investigate the mechanism through which founder status affects firm value. We test the relevant transaction hypothesis that states that founder-managers may act for the controlling family and are more concerned with its associated private income stream than with maximizing the value of the firm.

Relevant transaction hypothesis can be tested by adding a new variable relevant transaction, which equals "1" if founders (for founder-managed firms) or CEOs (for professional-managed firms) serve as the CEO or control more than $10 \%$ ownership of another firm, or if the sample firm belongs to a business family, and " 0 " otherwise. Data of relevant transactions are manually collected from firms' prospectuses and annual proxy statements in the SEDAR filling system. Before testing this hypothesis, we compare the relevant transaction percentage between founder- and non-founder-controlled firms. Of the 75 founder-CEO firms, 51 (or 68\%) are related to relevant transactions, compared with 18 (or 28.57\%) in professionally managed firms. Similar results are found for directors, with 60 out of $92(65.22 \%)$ in founder-directors and 9 out of 46 (19.57\%) in their counterparts. Hence, the assumption that relevant transactions are more involved in founder-firms, thus damaging firm value, seems possible.

Table 9 shows the tests results for the relevant transaction hypothesis, of which Panel A measured firm performance by Tobin's Q and Panel B by survival probability. For each table, Columns 1 and 3 list the regression results before adding the relevant transaction dummies for the founder-CEO and founder-director effect. Columns 2 and 4 are the corresponding comparative results after controlling for relevant transaction. If the relevant transaction hypothesis is helpful in explaining the negative relationship, we expect the absolute 
value of the founder-status coefficient to decrease and even to become insignificant. The relevant transaction hypothesis is more reasonable if the coefficient of the relevant transaction dummy is significant and negative. In Panel A of Table 9, when firm performance is measured by Tobin's Q, relevant transaction dummies are significantly negative, while founder-status coefficients become insignificant, and absolute values of the t-statistics sharply decline. More specifically, the coefficient estimate of relevant transaction is -0.6226 in founder-CEO samples and -0.5313 in founder-director samples, with a significant level of $5 \%$ and $10 \%$, respectively. When firm performance is measured by survival status in Panel B, we can also see that founder-status coefficients become insignificant, although relevant transaction dummies are also not related. Therefore, the relevant transaction hypothesis explains at least part of the negative correlation between founder status and firm value. Therefore, we find some support for Hypothesis III.

Table 9. Tests of relevant transaction hypothesis

\begin{tabular}{|c|c|c|c|c|}
\hline \multicolumn{5}{|c|}{ A. Firm performance measured by Tobin's $Q$} \\
\hline & Model 1 & Model 2 & Model 3 & Model 4 \\
\hline Intercept & $4.2637(3.25)^{* * *}$ & $4.0897(3.15)^{* * *}$ & $4.5327(3.47)^{* * *}$ & $4.2879(3.29)^{* * *}$ \\
\hline Founder-CEO & $-0.4308(-1.35)$ & $-0.1674(-0.49)$ & - & - \\
\hline Founder-director & - & - & $-0.6535(-2.08)^{* *}$ & $-0.4338(-1.29)$ \\
\hline Relevant transaction & - & $-0.6226(-2.01)^{* *}$ & - & $-0.5313(-1.73)^{*}$ \\
\hline Total asset turnover & $-0.0306(-0.08)$ & $0.0855(0.23)$ & $-0.0354(-0.10)$ & $0.0590(0.16)$ \\
\hline Long-term-debt-to-asset ratio & $0.2900(0.45)$ & $0.2618(0.41)$ & $0.2656(0.42)$ & $0.2752(0.44)$ \\
\hline Firm size & $-0.3087(-3.21)^{* * *}$ & $-0.2995(-3.15)^{* * *}$ & $-0.2928(-3.06)^{* * *}$ & $-0.2860(-3.01) * * *$ \\
\hline Firm age & $-0.0075(-0.77)$ & $-0.0105(-1.08)$ & $-0.0102(-1.04)$ & $-0.0122(-1.25)$ \\
\hline Mining & $0.0692(0.16)$ & $0.0644(0.15)$ & $-0.0182(-0.04)$ & $0.0113(0.03)$ \\
\hline Manufacturing & $0.6950(1.48)$ & $0.7008(1.51)$ & $0.6367(1.36)$ & $0.6649(1.44)$ \\
\hline Financial crisis & $-0.6418(-2.08)^{* *}$ & $-0.6783(-2.23)^{* *}$ & $-0.6301(-2.07)^{* *}$ & $-0.6585(-2.18)^{* *}$ \\
\hline Venture capital involvement & $0.2305(0.43)$ & $0.1296(0.24)$ & $0.2762(0.52)$ & $0.1668(0.31)$ \\
\hline BCOM change (\%) & $0.0178(2.21)^{* *}$ & $0.0170(2.13)^{* *}$ & $0.0176(2.21)^{* *}$ & $0.0170(2.15)^{* *}$ \\
\hline CEO tenure & $-0.0243(-0.46)$ & $-0.0370(-0.7)$ & $-0.0282(-0.55)$ & $-0.0352(-0.69)$ \\
\hline CEO ownership (\%) & $0.1328(2.60)^{* *}$ & $0.1214(2.39)^{* *}$ & $0.1274(2.62)^{* * *}$ & $0.1236(2.56)^{* *}$ \\
\hline CEO ownership squared & $-0.0032(-2.94)^{* * *}$ & $-0.0028(-2.64)^{* * *}$ & $-0.0030(-2.90)^{* * *}$ & $-0.0028(-2.74) * * *$ \\
\hline Board size & $-0.0612(-0.09)$ & $0.1731(0.27)$ & $-0.0254(-0.04)$ & $0.1647(0.25)$ \\
\hline Principal shareholder ownership (\%) & $0.0089(1.34)$ & $0.0082(1.26)$ & $0.0079(1.21)$ & $0.0075(1.15)$ \\
\hline Insider ownership (\%) & $-0.0613(-1.78)^{*}$ & $-0.0591(-1.73)^{*}$ & $-0.0599(-1.76)^{*}$ & $-0.0594(-1.76)^{*}$ \\
\hline Insider ownership squared & $0.0012(2.11)^{* *}$ & $0.0011(2.00)^{* *}$ & $0.0012(2.07)^{* *}$ & $0.0011(2.02)^{* *}$ \\
\hline Independent board member (\%) & $-0.0097(-1.07)$ & $-0.0099(-1.1)$ & $-0.0107(-1.19)$ & $-0.0104(-1.17)$ \\
\hline F-value & 3.90 & 4.00 & 4.12 & 4.12 \\
\hline Adj. $R^{2}$ & 0.28 & 0.29 & 0.29 & 0.30 \\
\hline \multicolumn{5}{|c|}{ B. Firm performance measured by survival status } \\
\hline Intercept & $3.7885(2.72)^{*}$ & $3.6047(2.41)$ & $4.2109(3.26)^{*}$ & $3.9768(2.82)^{*}$ \\
\hline Founder-CEO & $-0.9987(3.60)^{*}$ & $-0.8923(2.63)$ & - & - \\
\hline Founder-director & - & - & $-1.0018(3.25)^{*}$ & $-0.8845(2.30)$ \\
\hline Relevant transaction & - & $-0.3352(0.42)$ & - & $-0.3238(0.40)$ \\
\hline Total asset turnover & $-1.0214(3.43)^{*}$ & $-0.9695(3.02)^{*}$ & $-1.0536(3.70)^{*}$ & $-0.9999(3.24)^{*}$ \\
\hline Long-term-debt-to-asset ratio & $0.6358(0.37)$ & $0.6803(0.39)$ & $0.4881(0.23)$ & $0.5310(0.26)$ \\
\hline Firm size & $-0.1044(0.43)$ & $-0.0926(0.38)$ & $-0.0911(0.34)$ & $-0.0812(0.26)$ \\
\hline Firm age & $0.0704(3.02)^{*}$ & $0.0664(2.58)$ & $0.0725(2.88)^{*}$ & $0.0683(2.49)$ \\
\hline Mining & $-0.2898(0.18)$ & $-0.2955(0.18)$ & $-0.4188(0.38)$ & $-0.4101(0.35)$ \\
\hline Manufacturing & $-1.1651(2.36)$ & $-1.148(2.27)$ & $-1.2039(2.54)$ & $-1.1807(2.42)$ \\
\hline Financial crisis & $-0.4839(0.98)$ & $-0.5086(1.07)$ & $-0.4945(1.04)$ & $-0.5259(1.15)$ \\
\hline Venture capital involvement & $0.3728(0.19)$ & $0.306(0.13)$ & $0.4730(0.31)$ & $0.3928(0.21)$ \\
\hline BCOM change $(\%)$ & $-0.0360(7.26)^{* * *}$ & $-0.0364(7.40)^{* * *}$ & $-0.0370(7.68)^{* * *}$ & $-0.0372(7.77)^{* * *}$ \\
\hline CEO tenure & $-0.0385(0.17)$ & $-0.0432(0.21)$ & $-0.0612(0.47)$ & $-0.0639(0.50)$ \\
\hline CEO ownership (\%) & $0.1037(6.80)^{* * *}$ & $0.1074(6.98)^{* * *}$ & $0.0972(6.36)^{* *}$ & $0.1011(6.57)^{* *}$ \\
\hline Board size & $-0.2760(0.06)$ & $-0.1021(0.01)$ & $-0.2480(0.05)$ & $-0.0882(0.01)$ \\
\hline Principal shareholder ownership (\%) & $-0.0113(1.24)$ & $-0.0115(1.27)$ & $-0.0128(1.38)$ & $-0.0121(1.35)$ \\
\hline Insider ownership (\%) & $-0.0305(2.17)$ & $-0.0326(2.39)$ & $-0.0308(2.21)$ & $-0.0327(2.42)$ \\
\hline Independent board member (\%) & $-0.0161(1.05)$ & $-0.0164(1.10)$ & $-0.0181(1.41)$ & $-0.0180(1.39)$ \\
\hline Likelihood ratio & 29.96 & 30.39 & 29.68 & 30.07 \\
\hline
\end{tabular}

Note. Wald chi-square values are in parentheses following the coefficient estimates.

*** Means significant at the $1 \%$ level. ** Means significant at the $5 \%$ level. * Means significant at the $10 \%$ level. 
In addition, Canada is notable for its plenteous natural resources, including energy sources (oil, gas, natural gas, and uranium), forests, and mining. Accordingly, an incredibly high percentage of Canadian firms are in the natural-resources-related industry, with 80 out of 138 in our sample belonging to the mining sector (see details in Table 1). For U.S. market, high technology firms, including electric and communications, are a big portion of IPO firms. The operation of natural resources industry, in our point of view, relies more on effectively managing capital and employees, of which professional managers are specialists, contrasting with high technology firms, of which the creativity of its founder plays a huge role.

\section{Conclusion}

In this paper, we explore the impacts of founder status on firm value. Although this topic has been largely investigated, no empirical work has explored the Canadian IPO market. Therefore, we pioneer these efforts.

We find in the Canadian IPO market founder status has no influence on firm value, measured by ROA, while founder-firms underperform professionally managed firms, measured by Tobin's Q. These findings are robust when founders serve as chair members. Founder status is significantly negative related with survival probability, suggesting that founder-managed firms underlive their counterparts. The negative effects of founder-CEO and founder-director are consistent with Dittmar and Servaes (2005), Lauterbach and Vaninsky (1999), and Schulze et al. (2001), who demonstrate that the performance of founder-managed firms is inferior to that of professionally managed firms. The negative relationship is proven to be explained by the relevant transaction hypothesis, which states that founder-managers may act for the controlling family and are more concerned with the associated private income stream than with maximizing the value of the firm.

We also consider the industry characteristics hypothesis, where we planned to test the founder-status effect mainly on the high technology industry. If this hypothesis holds, we expect founders' creativity to increase firm value and a positive relationship to exist. Unfortunately, due to the limitation in the observation number, only 11 firms are in the transportation, communications, electric, gas, and sanitary service industry, of which only 5 firms are in communications and electric. Running regressions and testing the industry characteristics hypothesis is made impossible by a lack of observations. We hope further researchers will fill the gap in explaining the negative founder-status effect.

The results of this research should be meaningful to several groups of organizational stakeholders. Financial investors could make better decisions from knowing that founder-managed firms generally underperform professional-managed firms. The prospective employees of founder-managed firms who will sometimes receive compensation tied to the firms' market performance also should be interested in our results. Finally, the differential performance between founder- and non-founder-managed firms should be of interest to the founders themselves for succession planning.

Our results are also relevant for policy makers. Specifically, policy makers might discourage concentration of wealth in families. Policy makers can also formulate rules that limit the power of chief executive officers who own significant stakes in other companies. Specifically, the companies with family ties may be required to have an independent board. Similarly these companies may also be required to report all 'related party transactions' for approval to board of directors. This might reduce 'tunneling' by founder managers who belong to a family owned business group.

The findings and implications of this research should be considered in light of its limitations. Three limitations are most noteworthy. First, due to information unavailability of Canada stock market, only 138 observations are collected in our sample. Running regressions and testing the industry characteristics hypothesis is made impossible by a lack of observations. Second, although this paper finds that founder-managed firms are associated with poor performance in one year after IPO, it is unclear whether such an effect will last in the long-run. Third, the possibility of reverse causality, in which poor performance makes outsider managers reluctant to take over the firm, is not tested. Usually, instrumental variable regression is the method of conducting a causality test. However, data concerning some most frequently employed instrumental variables, such as number of founders and dead founders, are unobtainable for Canadian firms. Further research can focus more on Canadian firms and make improvements in line with these limitations.

\section{References}

Adams, R., Almeida, H., \& Ferreira, D. (2005). Powerful CEOs and their impact on corporate performance. Rev. Financ. Stud., 18(4), 1403-1432. http://dx.doi.org/10.1093/rfs/hhi030

Adams, R., Almeida, H., \& Ferreira, D. (2009). Understanding the relationship between founder-CEOs and firm performance. J. Empir. Financ., 16(1), 136-150. http://dx.doi.org/10.1016/j.jempfin.2008.05.002 
Aldrich, H. E., \& Fiol, C. M. (1994). Fools rush in? The institutional context of industry creation. Acad. Manage. Rev., 19(4), 645-670.

Anderson, R. C., \& Reeb, D. M. (2003a). Founding-family ownership and firm performance: Evidence from the S\&P 500. J. Financ., 58(3), 1301-1328. http://dx.doi.org/10.1111/1540-6261.00567

Anderson, R. C., \& Reeb, D. M. (2003b). Founding-Family Ownership, Corporate Diversification, and Firm Leverage. J. Law Econ., 46(2), 653-684. http://dx.doi.org/10.1086/377115

Anderson, R. C., Mansi, S. A., \& Reeb, D. M. (2003). Founding family ownership and the agency cost of debt. J. Financ. Econ., 68(2), 263-285. http://dx.doi.org/10.1016/S0304-405X(03)00067-9

Andres, C. (2008). Large shareholders and firm performance-An empirical examination of founding-family ownership. J. Corp. Financ., 14(4), 431-445. http://dx.doi.org/10.1016/j.jcorpfin.2008.05.003

Attig, N. (2007). Excess control and the risk of corporate expropriation: Canadian evidence. Can. J. Adm. Sci., 24(2), 94-106.

Brown, K. C., Dittmar, A., \& Servaes, H. (2005). Corporate governance, incentives, and industry consolidations. Rev. Financ. Stud., 18(1), 241-270. http://dx.doi.org/10.1093/rfs/hhh009

Burton, M. D., Sørensen, J. B., \& Beckman, C. M. (2002). Coming from good stock: Career histories and new venture formation. Working Paper.

Chandler, A. D. (2009). Scale and Scope: The Dynamics of Industrial Capitalism. Cambridge: Harvard University Press.

Chen, X. P., Yao, X., \& Kotha, S. (2009). Entrepreneur passion and preparedness in business plan presentations: A persuasion analysis of venture capitalists' funding decisions. Acad. Manage. J., 52(1), 199-214. http://dx.doi.org/10.5465/AMJ.2009.36462018

Chourou, L. (2010). Compensation of owner managers in Canadian family-owned businesses: expropriation of minority shareholders. Can. J. Adm. Sci., 27(2), 95-106.

Cohen, L., Diether, K., \& Malloy, C. (2013). Misvaluing innovation. Rev. Financ. Stud., 26(3), 635-666. http://dx.doi.org/10.1093/rfs/hhs183

Daniels, R. J., \& Halpern, P. (1996). Too close for comfort: the role of the closely held public corporation in the Canadian economy and the implications for public policy. Can. Bus., 11-62.

Demsetz, H., \& Lehn, K. (1985). The structure of corporate ownership: Causes and consequences. J. Polit. Econ., 93(6), 1155-1177.

Demsetz, H., \& Villalonga, B. (2001). Ownership structure and corporate performance. J. Corp. Financ., 7(3), 209-233. http://dx.doi.org/10.1016/S0929-1199(01)00020-7

Eisenhardt, K. M., \& Schoonhoven, C. B. (1990). Organizational growth: Linking founding team, strategy, environment, and growth among US semiconductor ventures, 1978-1988. Admin. Sci. Quart., 35(3), 504-529.

Erickson, J., Parka, Y. W., Reisingb, J., \& Shinc, H. H. (2005). Board composition and firm value under concentrated ownership: The Canadian evidence. Pac.-Basin Financ. J., 13(4), 387-410. http://dx.doi.org/10.1016/j.pacfin.2004.11.002

Fahlenbrach, R. (2009). Founder-CEOs, investment decisions, and stock market performance. J. Financ. Quant. Anal., 44(2), 439-466. http://dx.doi.org/10.1017/S0022109009090139

Hallen, B. L. (2008). The causes and consequences of the initial network positions of new organizations: From whom do entrepreneurs receive investments? Admin. Sci. Quart., 53(4), 685-718. http://dx.doi.org/10.2189/asqu.53.4.685

He, L. (2008). Do founders matter? A study of executive compensation, governance structure and firm performance. J. Bus. Venturing, 23(3), 257-279. http://dx.doi.org/10.1016/j.jbusvent.2007.02.001

Jain, B. A., \& Tabak, F. (2008). Factors influencing the choice between founder versus non-founder CEOs for IPO firms. J. Bus. Venturing, 23(1), 21-45. http://dx.doi.org/10.1016/j.jbusvent.2005.11.001

James, H. S. (1999). Owner as manager, extended horizons and the family firm. Int. J. Econ. Bus., 6(1), 41-55.

Jayaraman, N., Khorana, A., Nelling, E., \& Covin, J. (2000). Research notes and commentaries CEO founder status and firm financial performance. Strateg. Manage. J., 21(12), 1215-1224. 
http://dx.doi.org/10.1002/1097-0266(200012)21:12

Jensen, M. C., \& Meckling, W. H. (1976). Theory of the firm: Managerial behavior, agency costs and ownership structure. J. Financ. Econ., 3(4), 305-360.

Kaplan, S. N., Sensoy, B. A., \& Strömberg, P. (2009). Should investors bet on the jockey or the horse? Evidence from the evolution of firms from early business plans to public companies. J. Financ., 64(1), 75-115. http://dx.doi.org/10.1111/j.1540-6261.2008.01429.x

King, M. R., \& Santor, E. (2008). Family values: Ownership structure, performance and capital structure of Canadian firms. J. Bank. Financ., 32(11), 2423-2432. http://dx.doi.org/10.1016/j.jbankfin.2008.02.002

Lauterbach, B., \& Vaninsky, A. (1999). Ownership structure and firm performance: Evidence from Israel. $J$. Manage. Govern., 3(2), 189-201.

Li, F., \& Srinivasan, S. (2011). Corporate governance when founders are directors. J. Financ. Econ., 102(2), 454-469. http://dx.doi.org/10.1016/j.jfineco.2010.11.006

Malmendier, U., \& Tate, G. (2008). Who makes acquisitions? CEO overconfidence and the market's reaction. J. Financ. Econ., 89(1), 20-43. http://dx.doi.org/10.1016/j.jfineco.2007.07.002

Markin, A. (2004). Family ownership and firm performance in Canada. Diss. Faculty of Business Administration-Simon Fraser University.

McConnell, J. J., \& Servaes, H. (1990). Additional evidence on equity ownership and corporate value. J. Financ. Econ., 27(2), 595-612.

Morck, R., \& Yeung, B. (2003). Agency problems in large family business groups. Entrep. Theory Pract., 27(4), 367-382. http://dx.doi.org/10.1111/1540-8520.t01-1-00015

Morck, R., David, S., \& Bernard, Y. (2000). Inherited Wealth, Corporate Control \& Economic Growth: The Canadian Disease? In Randall Morck (Ed.), Concentrated Corporate Ownership (pp. 319-69). National Bureau of Economic Research \& University of Chicago Press.

Morck, R., Shleifer, A., \& Vishny, R. W. (1988). Management ownership and market valuation: An empirical analysis. J. Financ. Econ., 20(1-2), 293-315.

Nelson, T. (2003). The persistence of founder influence: Management, ownership, and performance effects at initial public offering. Strateg. Manage. J., 24(8), 707-724. http://dx.doi.org/10.1002/smj.328

Palia, D. (2001). The endogeneity of managerial compensation in firm valuation: A solution. Rev. Financ. Stud., 14(3), 735-764. http://dx.doi.org/10.1093/rfs/14.3.735

Pérez-González, F. (2006). Inherited control and firm performance. Am. Econ. Rev., 96(5), 1559-1588. DOI: 10.1257/aer.96.5.1559

Sacristán-Navarro, M., Gómez-Ansón, S., \& Cabeza-García, L. (2011). Family ownership and control, the presence of other large shareholders, and firm performance: Further evidence. Fam. Bus. Rev., 24(1), 71-93. http://dx.doi.org/10.1177/0894486510396705

Schulze, W. S., Lubatkin, M. H., Dino, R. N., \& Buchholtz, A. K. (2001). Agency relationships in family firms: Theory and evidence. Organ. Sci., 12(2), 99-116. http://dx.doi.org/10.1287/orsc.12.2.99.10114

Shane, S., \& Stuart, T. (2002). Organizational endowments and the performance of university start-ups. Manage. Sci., 48(1), 154-170. http://dx.doi.org/10.1287/mnsc.48.1.154.14280

Stinchcombe, A. L., \& March, J. G. (1965). Social structure and organizations. Adv. Strateg. Manage., 17, 229-259.

Tsao, C. W., Chen, S. J., Lin, C. S., \& Hyde, W. (2009). Founding-family ownership and firm performance: The role of high-performance work systems. Fam. Bus. Rev., 22(4), 319-332. http://dx.doi.org/10.1177/0894486509339322

Villalonga, B., \& Amit, R. (2006). How do family ownership, control and management affect firm value? J. Financ. Econ., 80(2), 385-417. http://dx.doi.org/10.1016/j.jfineco.2004.12.005

Villalonga, B., \& Amit, R. (2009). How are US family firms controlled? Rev. Financ. Stud., 22(8), 3047-3091. http://dx.doi.org/10.1093/rfs/hhn080

Willard, G. E., Krueger, D. A., \& Feeser, H. R. (1992). In order to grow, must the founder go: A comparison of performance between founder and non-founder managed high-growth manufacturing firms. J. Bus. 
Venturing, 7(3), 181-194. http://dx.doi.org/10.1016/0883-9026(92)90025-M

\section{Appendix A}

Table A1. Description of variables

\begin{tabular}{|c|c|c|}
\hline Variable & Description & Source \\
\hline Tobin's Q & $\begin{array}{l}\text { Tobin's } Q \text { is measured by dividing market value of assets by book value of assets, where } \\
\text { market value of assets = total assets }+ \text { market equity }- \text { book equity, market equity = } \\
\text { common shares outstanding*fiscal year closing price, book equity = total assets }- \text { total } \\
\text { liability - preferred stock }+ \text { deferred tax }+ \text { convertible debt, and Book value of assets = } \\
\text { total assets. }\end{array}$ & Compustat \\
\hline ROA & $\begin{array}{l}\mathrm{ROA} \text { is calculated as operating income before depreciation (OIBDP) scaled by the } \\
\text { average book value of total assets. }\end{array}$ & Compustat \\
\hline Survival Status & $\begin{array}{l}\text { Survival status equals } 1 \text { if firms still exist in the public stock market and } 0 \text { if firms have a } \\
\text { death event. }\end{array}$ & Compustat \\
\hline Founder-CEO & Founder-CEO equals 1 if the founder or co-founder is $\mathrm{CEO}$ and 0 otherwise. & SEDAR, google \\
\hline Founder-director & $\begin{array}{l}\text { Founder-director equals } 1 \text { if the founder or co-founder is on the board (not necessarily a } \\
\text { chairman) and } 0 \text { otherwise. }\end{array}$ & SEDAR, google \\
\hline Relevant Transaction & $\begin{array}{l}\text { Relevant transaction equals } 1 \text { if founders (for founder-managed firms) or CEOs (for } \\
\text { professional-managed firms) serve as CEO or control more than } 10 \% \text { ownership of } \\
\text { another firm, or if the sample firm belongs to a business family, and } 0 \text { otherwise. }\end{array}$ & SEDAR \\
\hline Total Asset Turnover & $\begin{array}{l}\text { Total asset turnover is calculated by dividing net sales by average total asset which is the } \\
\text { mean of current year total asset and previous year total assets. }\end{array}$ & Compustat \\
\hline $\begin{array}{l}\text { Long-Term-Debt-to-As } \\
\text { set Ratio }\end{array}$ & $\begin{array}{l}\text { Long-term-debt-to-asset ratio is the ratio of long-term debt (include the current portion of } \\
\text { long-term debt) to total assets. }\end{array}$ & Compustat \\
\hline Firm Size & Firm size is the natural log of the book value of total assets. & Compustat \\
\hline Firm Age & Firm age is measured as the natural log of the number of years since the firm's inception. & SEDAR \\
\hline Industry Dummies & $\begin{array}{l}\text { Industry dummies are constructed based on two-digit SIC codes and adjusted on the } \\
\text { observation numbers of different industry. }\end{array}$ & Compustat \\
\hline $\begin{array}{l}\text { Financial Crisis } \\
\text { Dummy }\end{array}$ & $\begin{array}{l}\text { Firms went public during the financial crisis } 2007-2008 \text { are assigned } 1 \text { to this variable and } \\
\text { zero otherwise }\end{array}$ & - \\
\hline $\begin{array}{l}\text { Venture Capital } \\
\text { Involvement }\end{array}$ & $\begin{array}{l}\text { Venture capital involvement equals } 1 \text { if the IPO issuing firm received venture capital } \\
\text { backing and } 0 \text { otherwise. }\end{array}$ & SDC \\
\hline BCOM Change & The Bloomberg Commodity Index (BCOM) change during the year after IPO. & Bloomberg \\
\hline CEO Tenure & CEO tenure measures how long CEO is nominated. & SEDAR \\
\hline CEO Ownership & CEO ownership measures the percentage of firm ownership held by the CEO. & SEDAR \\
\hline Board Size & Board size is the natural log of number of directors on the board. & SEDAR \\
\hline $\begin{array}{l}\text { Principal Shareholder } \\
\text { Ownership }\end{array}$ & $\begin{array}{l}\text { Principal shareholder ownership is the percentage of equity hold by principal } \\
\text { shareholders, where we define principal shareholders as shareholders who own at least } \\
10 \% \text { of a company's common shares. }\end{array}$ & SEDAR \\
\hline Insider Ownership & $\begin{array}{l}\text { Insider ownership measures as dividing the number of common stock of all nominees, } \\
\text { directors and executive officers by the total number of common stocks outstanding. }\end{array}$ & SEDAR \\
\hline $\begin{array}{l}\text { Independent Board } \\
\text { Members }\end{array}$ & Independent board members measures the percentage of independent board members. & SEDAR \\
\hline
\end{tabular}

\section{Copyrights}

Copyright for this article is retained by the author(s), with first publication rights granted to the journal.

This is an open-access article distributed under the terms and conditions of the Creative Commons Attribution license (http://creativecommons.org/licenses/by/4.0/). 